\title{
Microbial Respiration, the Engine of Ocean Deoxygenation
}

\author{
Carol Robinson* \\ Centre for Ocean and Atmospheric Sciences, School of Environmental Sciences, University of East Anglia, Norwich, \\ United Kingdom
}

\section{OPEN ACCESS}

Edited by:

Emilio Garcia-Robledo,

University of Cádiz, Spain

Reviewed by:

Carolin Regina Löscher,

University of Southern Denmark,

Denmark

Thomas Smith Weber

University of Rochester, United States

Helmut Maske,

Ensenada Center for Scientific

Research and Higher Education

(CICESE), Mexico

*Correspondence:

Carol Robinson

carol.robinson@uea.ac.uk

Specialty section:

This article was submitted to

Marine Biogeochemistry,

a section of the journal

Frontiers in Marine Science

Received: 10 August 2018

Accepted: 31 December 2018

Published: 17 January 2019

Citation:

Robinson C (2019) Microbial Respiration, the Engine of Ocean

Deoxygenation.

Front. Mar. Sci. 5:533.

doi: 10.3389/fmars.2018.00533
Microbial plankton respiration is the key determinant in the balance between the storage of organic carbon in the oceans or its conversion to carbon dioxide with accompanying consumption of dissolved oxygen. Over the past 50 years, dissolved oxygen concentrations have decreased in many parts of the world's oceans, and this trend of ocean deoxygenation is predicted to continue. Yet despite its pivotal role in ocean deoxygenation, microbial respiration remains one of the least constrained microbial metabolic processes. Improved understanding of the magnitude and variability of respiration, including attribution to component plankton groups, and quantification of the respiratory quotient, would enable better predictions, and projections of the intensity and extent of ocean deoxygenation and of the integrative impact of ocean deoxygenation, ocean acidification, warming, and changes in nutrient concentration and stoichiometry on marine carbon storage. This study will synthesize current knowledge of respiration in relation to deoxygenation, including the drivers of its variability, identify key unknowns in our ability to project future scenarios and suggest an approach to move the field forward.

Keywords: microbial respiration, respiratory quotient, ocean deoxygenation, ocean acidification, multiple stressors

\section{INTRODUCTION}

Dissolved oxygen $\left(\mathrm{O}_{2}\right)$ is fundamental to all aerobic life and thus plays a major role in marine microbial ecology and the biogeochemical cycling of elements such as carbon, nitrogen, phosphorus and sulfur. The measurement of seawater $\mathrm{O}_{2}$ began during the 1873-1876 HMS Challenger expedition, and $\mathrm{O}_{2}$ continues to be the most commonly measured indicator of marine biogeochemistry, with the current global database amounting to millions of measurements (Keeling et al., 2010; Schmidtko et al., 2017). Time series data over the past 50 years show declining $\mathrm{O}_{2}$ in many regions of the world's oceans, and a significant increase in the aerial extent of oxygen minimum zones (OMZs) in the eastern tropical North Atlantic (ETNA) and equatorial Pacific. Stramma et al. (2008) determined the decrease in $\mathrm{O}_{2}$ for the region of the ETNA between $10-14^{\circ} \mathrm{N}$ and $20-30^{\circ} \mathrm{W}$ in the depth range $300-700 \mathrm{~m}$ to be $0.09-0.34 \mu \mathrm{mol} \mathrm{kg}^{-1}$ year $^{-1}$ between 1960 and 2008 , while later studies revealed variations in this long term decline at interannual to multidecadal timescales consistent with natural climate variability (Brandt et al., 2015). The latest collation of global ocean dissolved oxygen data shows a decrease of more than $2 \%(4.8 \pm 2.1 \mathrm{pmol})$, in the global oceanic oxygen content since 1960 (Schmidtko et al., 2017), however, at regional scales the changes are more complex. Deutsch et al. (2014) showed evidence for a decrease in the extent of oxygen minimum zones in the tropical Pacific Ocean over most of the 20th century. This was 
related to weakening easterly trade winds in a warming climate which decrease the intensity of upwelling and therefore the magnitude of biological production, export of organic carbon and respiratory oxygen demand. In the coastal zone, low or zero oxygen conditions are induced by anthropogenic nutrient enrichment and eutrophication, with the number of these coastal zone hypoxic sites having increased by an order of magnitude since the 1960s (Diaz and Rosenberg, 2008). This "deoxygenation" of the open and coastal ocean is predicted to continue. Coupled climate - marine biogeochemical models all project a continued long term decrease in the global ocean $\mathrm{O}_{2}$ inventory of between 1 and $7 \%$ by 2100 (Bopp et al., 2002; Keeling and Garcia, 2002; Keeling et al., 2010). Henson et al. (2017) investigated the trend in a multi-model mean ensemble of the Coupled Model Inter-comparison Project Phase 5 (CMIP5) output, run under a "business-as-usual" scenario (RCP8.5). This suggested that most of the world's oceans will experience a 1-2\% decrease in the oxygen inventory per decade with respect to the mean of 1986-2005. However, the regions where temperature and $\mathrm{O}_{2}$ changes are likely to have the greatest impact on marine ecosystems and biogeochemistry, the poles and the tropics, including the major eastern boundary upwelling systems where oxygen minimum zones occur (Gruber, 2011), are also the regions where inter-model agreement is low (Henson et al., 2017).

A number of physical, ecological, and biogeochemical mechanisms could contribute to the process of deoxygenation (Figure 1) including:

(1) The direct effect of increasing temperature reducing the solubility of oxygen in seawater. This physical chemical process is well constrained, with estimates of a decrease in $\mathrm{O}_{2}$ of ca. $5 \mathrm{mmol} \mathrm{m}^{-3}$ for each $1^{\circ} \mathrm{C}$ increase in water temperature (Deutsch et al., 2011). Within the upper $1000 \mathrm{~m}, 50 \%$ of the observed $\mathrm{O}_{2}$ loss is attributed to changes in solubility. This percentage decreases to $25 \%$ of the $\mathrm{O}_{2}$ loss in the upper $2000 \mathrm{~m}$ and $15 \%$ of the $\mathrm{O}_{2}$ loss over the full oceanic depth (Schmidtko et al., 2017).

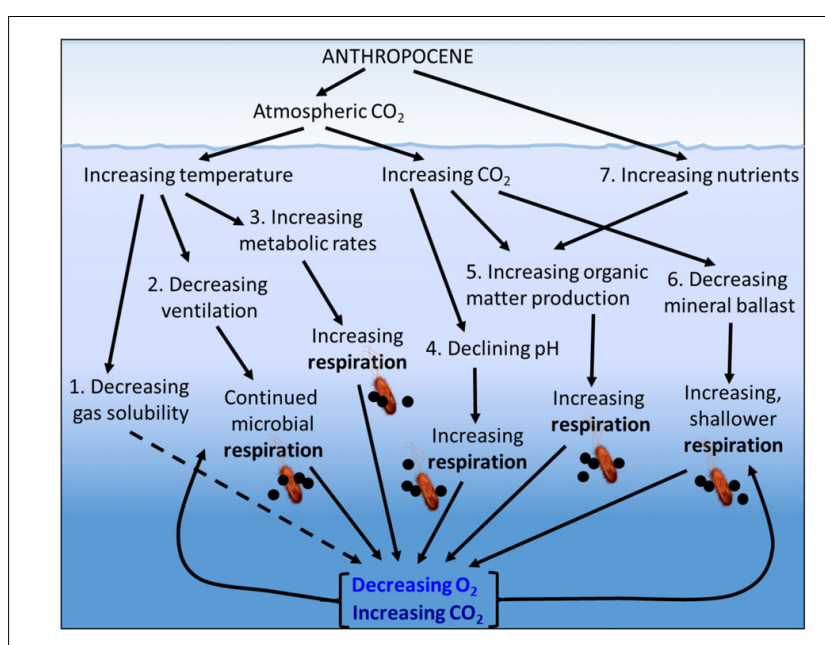

FIGURE 1 | Potential physical, ecological and biogeochemical mechanisms contributing to ocean deoxygenation in the Anthropocene.
(2) The indirect effect of increasing sea surface temperatures causing increased surface ocean stratification and reduced ventilation of the deep ocean, therefore increasing the length of time that deep water is separated from contact with the atmosphere. This delays the re-equilibration of dissolved oxygen to atmospheric concentrations while microbial degradation of organic matter associated with aerobic respiration consuming oxygen and producing carbon dioxide $\left(\mathrm{CO}_{2}\right)$ continues.

(3) The direct effect of increasing temperature on the metabolic rates of the plankton, with the expectation that for the same increase in temperature, heterotrophic processes such as microbial respiration which consume oxygen will increase more than autotrophic processes such as photosynthesis which produce oxygen (López-Urrutia et al., 2006; Wohlers et al., 2009), and that bacterioplankton growth efficiencies (the proportion of the carbon assimilated by bacterioplankton that is converted to biomass rather than being respired to $\mathrm{CO}_{2}$ ) decrease with increasing temperature (Rivkin and Legendre, 2001). A warming ocean is therefore expected to change the depth distribution of oxygen consumption, with an increase in shallower warmer waters and a decrease at depth due to the reduced supply of organic matter. Whether this redistribution of oxygen consumption will lead to a decrease or increase in average oxygen concentrations remains uncertain.

(4) The direct effect of increasing $\mathrm{CO}_{2}$ leading to increased bacterioplankton cell-specific respiration. The anthropogenically derived $\mathrm{CO}_{2}$ in the atmosphere which is causing global warming is also dissolving in seawater, leading to increasing $\mathrm{pCO}_{2}$ and decreasing seawater $\mathrm{pH}$ and carbonate ion concentration (ocean acidification). Elevated $\mathrm{pCO}_{2}$ has been shown to increase the activity of bacterioplankton extracellular enzymes such as $\alpha$ and $\beta$-glucosidase (Piontek et al., 2010, 2013) and enhance bacterioplankton respiration (James et al., 2017).

(5) The indirect effect of increased photosynthesis caused by increasing concentrations of seawater $\mathrm{CO}_{2}$. Increased $\mathrm{CO}_{2}$ can enhance photosynthesis, producing an increased amount of particulate organic material (Riebesell and Tortell, 2011), a greater proportion of exudation of dissolved organic material (DOM; Engel et al., 2004) and increased carbon:nitrogen and carbon:phosphorus ratios of the DOM (Riebesell et al., 2007), leading to increased microbial respiration.

(6) The indirect effect of reduced calcium carbonate ballast due to decreasing seawater $\mathrm{pH}$ and carbonate ion concentration. The reduction in plankton extra-cellular calcium carbonate reduces the sinking rate of the plankton cells allowing respiration to occur at a shallower depth (Barker et al., 2003), and potentially allows a greater proportion of the exposed organic material to be respired in a given time.

(7) The indirect effect of increased coastal discharge of inorganic nutrients leading to increased primary production and thus increased phytoplankton derived particulate and dissolved organic carbon (or 
eutrophication), which when degraded by heterotrophic bacteria supports increased microbial respiration. The indirect effect of increased discharge of inorganic nutrients and/or increased phytoplankton production of labile dissolved organic carbon "priming" the degradation of previously recalcitrant dissolved organic carbon (Jiao et al., 2011). The indirect effect of increased pollutionderived atmospheric deposition of soluble iron and fixed nitrogen leading to increased primary production and then increased respiration (Ito et al., 2016).

The inter-dependencies and feedbacks between these mechanisms mean that their individual effects on deoxygenation can be counteracted or exacerbated. For example, increased stratification due to increased surface temperature will reduce nutrient supply to the surface ocean, reducing primary production by an estimated $24 \%$ by the year 2300 when RCP8.5 predicts a fivefold increase in atmospheric $\mathrm{CO}_{2}$ (Moore et al., 2018) which will offset the $27 \%$ increase in primary production due to carbon fertilization, estimated for a doubling of atmospheric $\mathrm{CO}_{2}$ (Riebesell et al., 2007).

Apart from the temperature related decrease in oxygen solubility and ocean ventilation, all of these potential mechanisms causing deoxygenation depend on microbial aerobic respiration, the metabolic process driven by the degradation of dissolved and particulate organic carbon, which consumes oxygen, produces carbon dioxide and generates energy in the form of adenosine triphosphate (ATP). Midwater microbial communities - predominantly bacterioplankton, archaeoplankton and zooplankton - are therefore central to the challenge that is ocean deoxygenation because they both influence and are influenced by decreasing oxygen concentrations. Since the depletion of oxygen caused by microbial respiration is always accompanied by an increase in $\mathrm{CO}_{2}$, ocean deoxygenation is always a dual stressor problem both oxygen and $\mathrm{CO}_{2}$ change (Brewer and Peltzer, 2009). Due to this complexity of feedbacks and interdependency, ocean deoxygenation is therefore a "wicked" problem contributing to the "super wicked" problem of climate change (Levin et al., 2012).

The aim of this paper is to explore this wicked problem from the perspective of microbial respiration, focusing on the key role that microbial respiration plays in enabling ocean deoxygenation and on how microbial respiration, and therefore the storage of carbon in the ocean, might be affected by ocean deoxygenation. I will build on previous reviews of microbial respiration (e.g., del Giorgio and Duarte, 2002; Robinson and Williams, 2005; Robinson, 2008; Arístegui et al., 2009; Regaudie-de-Gioux and Duarte, 2012, 2013) synthesizing what we know about midwater microbial respiration that could help us predict how microbial respiration might change in waters with reduced oxygen and increased carbon dioxide concentrations, and then identify areas of research that still need to be addressed and some emerging approaches that could be used.

\section{MICROBIAL RESPIRATION}

The magnitude and variability of marine microbial aerobic respiration is fundamental to deoxygenation, the formation of oxygen minimum zones and the efficiency of the biological carbon pump. Yet due to methodological limitations, the number of direct measurements and therefore our understanding of respiration, especially below the euphotic zone, is only loosely constrained.

\section{Measurement Methods}

The magnitude of midwater (i.e., between 100 and $1000 \mathrm{~m}$ depth range) respiration can be determined either from the oxygen consumption of an incubated water sample (Arístegui et al., 2005; Reinthaler et al., 2006; Baltar et al., 2010; Holtappels et al., 2014), from plankton electron transport system (ETS) activity (e.g., Packard et al., 2015; Osma et al., 2016; MartínezGarcía, 2017), from ${ }^{14} \mathrm{CO}_{2}$ production during incubations with ${ }^{14} \mathrm{C}$ labeled compounds (Hill et al., 2013), from measurements of bacterioplankton production and bacterioplankton growth efficiency $(\mathrm{BGE}=$ proportion of assimilated carbon used to produce bacterioplankton biomass) or from a time resolved estimate of the amount of oxygen consumed since a given water body left the sea surface where the dissolved oxygen concentration was in equilibrium with that in the atmosphere the apparent (AOU; Sarmiento and Gruber, 2006), true (TOU) or evaluated (EOU; Duteil et al., 2013) oxygen utilization. Combining the estimate of oxygen utilization with an estimate of ventilation age from the distribution of tritium, radiocarbon or chlorofluorocarbons (CFCs), gives an average oxygen utilization rate (OUR; Jenkins, 1987). The efficiency of mesopelagic remineralization can also be inferred from the vertical profile of particle flux derived from underwater imaging, sediment trap data or thorium isotope disequilibria (Guidi et al., 2015) or reconstructed from large-scale ocean nutrient distributions (Weber et al., 2016).

Midwater respiration rates $\left(60-300 \mu \mathrm{mol} \mathrm{O} \mathrm{m}^{-3} \mathrm{day}^{-1}\right)$ have been derived from direct measurements of oxygen consumption during incubations of 2-4 days. To minimize any potential artifacts due to such long incubations, data are only used when linearity in oxygen consumption and cell abundance are confirmed, or when significant relationships between oxygen consumption and bacterioplankton production during the incubations can be used with in situ bacterioplankton production measurements to "back-correct" the respiration to in situ values (Arístegui et al., 2005; Reinthaler et al., 2006; Mazuecos et al., 2015). The ETS method estimates the maximum activity $\left(\mathrm{V}_{\max }\right)$ of the enzymes associated with the respiratory electron transport system of both eukaryotes and prokaryotes under substrate (NADH, NADPH) saturation, and is therefore a maximum "potential" respiration rate rather than the actual respiration rate. $V_{\text {max }}$ is converted into rates of oxygen consumption using either an empirical relationship determined from bacterial cultures or application of an enzyme kinetic model (EKM). It therefore assumes an average relationship between enzyme mass and respiratory activity, and due to this assumption it has an estimated error of $31-38 \%$ (Packard et al., 
1988). A recent development of the ETS technique uses pyridine nucleotide concentrations and an EKM (Aguiar-González et al., 2012) to derive the actual respiration rate. This method has been used with cultured bacteria and zooplankton (Osma et al., 2016), but has not yet been tested in open waters.

A further modification of the ETS method derives respiration from the relationship between dissolved oxygen consumption and the in vivo reduction of 2-(p-iodophenyl)-3-(p-nitrophenyl)5-phenyltetrazolium chloride (INT) to INT-formazan (MartínezGarcía et al., 2009). Martínez-García (2017) presents the first sizefractionated mesopelagic respiration data from station ALOHA in the North Pacific Subtropical Gyre using the INT technique, to show vertical and seasonal variability in respiration ranging from 56 to $107 \mu \mathrm{mol} \mathrm{O}_{2} \mathrm{~m}^{-3}$ day $^{-1}$ in the $100-1000 \mathrm{~m}$ depth horizon. These data are around an order of magnitude higher than earlier ETS estimates $\left(1-7 \mathrm{~mol} \mathrm{O}_{2} \mathrm{~m}^{-2} \mathrm{y}^{-1} ; 3-25 \mu \mathrm{mol} \mathrm{O}_{2} \mathrm{~m}^{-3} \mathrm{day}^{-1}\right.$; Arístegui et al., 2003), which were calculated using a conversion factor derived from a senescent bacterial culture, suggesting that microbial communities in the mesopelagic ocean are much more active that previously assumed (Arístegui et al., 2009). Respiration can also be derived from the respiration of ${ }^{14} \mathrm{C}$ leucine by bacterioplankton cells. Hill et al. (2013) determined respiration in the range $0.07-1.9$ pmol leu $\mathrm{L}^{-1} \mathrm{~h}^{-1}$ between 20 and $160 \mathrm{~m}$ in the Atlantic Ocean after additions of ${ }^{14} \mathrm{C}$ leucine at close to ambient $\left(0.4 \mathrm{nmol} \mathrm{L}^{-1}\right)$ concentrations. Using ${ }^{3} \mathrm{H}$-leucine bioassay isotope dilution to determine prokaryote production, and published estimates of prokaryote growth efficiencies, Giering et al. (2014) calculated depth integrated (50-1000 m) North Atlantic prokaryote respiration to be $71 \mathrm{mg}$ $\mathrm{C} \mathrm{m}{ }^{-2}$ day $^{-1}$. Oxygen utilization rates including recent ones derived for the Pacific (Sonnerup et al., 2013, 2015) and Atlantic Oceans (Stanley et al., 2012) using transit time distributions, range from 0.3 to $50 \mu \mathrm{mol} \mathrm{O}_{2} \mathrm{~m}^{-3}$ day $^{-1}\left(0.03-18.2 \mathrm{~mol} \mathrm{O}_{2} \mathrm{~m}^{-2}\right.$ $\mathrm{y}^{-1}$; Table 1).

In the oxygen minimum zones (OMZ) where oxygen concentrations fall below $40 \mu \mathrm{mol} \mathrm{L}{ }^{-1}$ or, in the most intense OMZs below $20 \mu \mathrm{mol} \mathrm{L}{ }^{-1}$ (Paulmier and Ruiz-Pino, 2009), it is only relatively recently that techniques to accurately measure extremely low in situ oxygen concentrations and rates of oxygen consumption have become available. While Winkler titrations, electrochemical or optode sensors and oxygen isotope methods have detection limits around $0.1-1 \mu \mathrm{mol} \mathrm{L}{ }^{-1}$, the switchable trace oxygen (STOX) microsensor has a detection limit in the range 1-10 $\mathrm{nmol} \mathrm{L}^{-1}$ (Revsbech et al., 2009, 2011), and in water bodies containing concentrations of $\mathrm{O}_{2}$ less than $1 \mathrm{nmol}$ $\mathrm{L}^{-1}$, the ultra-sensitive Luminescence Measuring Oxygen Sensor (LUMOS) has a sensitivity of $7 \mathrm{pmol} \mathrm{L}^{-1}$ (Lehner et al., 2014, 2015). Good agreement was found between measurements of oxygen concentration and oxygen consumption made by STOX sensors, optode spots and membrane inlet mass spectrometric analysis of ${ }^{18-18} \mathrm{O}_{2}$ (Holtappels et al., 2014). Using these new nanomolar techniques, in situ oxygen and respiration measurements derived from consumption of oxygen, showed that aerobic respiration occurs efficiently at extremely low oxygen concentrations (Tiano et al., 2014; Kalvelage et al., 2015; GarciaRobledo et al., 2016). As well as the difficulty in measuring very low oxygen concentrations and rates of oxygen consumption,
TABLE 1 | Recent midwater (100-1000 m) respiration estimates derived from dissolved oxygen consumption during a bottle incubation $\left(\Delta \mathrm{O}_{2}\right)$, activity of the electron transport system (ETS), the reduction of the tetrazolium salt (INT), or the time resolved estimate of the amount of dissolved oxygen consumed since a water parcel was last in contact with the atmosphere, the oxygen utilization rate (OUR).

\begin{tabular}{|c|c|c|c|}
\hline Region & Method & $\begin{array}{l}\text { Respiration ( } \mu \mathrm{mol} \\
\left.\mathrm{O}_{2} \mathrm{~m}^{-3} \mathrm{day}^{-1}\right)\end{array}$ & Reference \\
\hline NE Atlantic & $\Delta \mathrm{O}_{2}$ & $80-350$ & Arístegui et al., 2005 \\
\hline N Atlantic & $\Delta \mathrm{O}_{2}$ & 50-200 & Reinthaler et al., 2006 \\
\hline $\begin{array}{l}\text { Mediterranean } \\
\text { Sea }\end{array}$ & $\Delta \mathrm{O}_{2}$ & $230-1650$ & Weinbauer et al., 2013 \\
\hline $\begin{array}{l}\text { S Atlantic and } \\
\text { Indian }\end{array}$ & $\Delta \mathrm{O}_{2}$ & $87-238$ & Mazuecos et al., 2015 \\
\hline NE Atlantic & ETS & $120 \pm 14$ & Arístegui et al., 2005 \\
\hline N Atlantic & ETS & $20-50$ & Reinthaler et al., 2006 \\
\hline Atlantic & ETS & $66-88$ & Baltar et al., 2009a,b \\
\hline N Atlantic & ETS & $7-16$ & $\begin{array}{l}\text { Fernández-Castro } \\
\text { et al., } 2016\end{array}$ \\
\hline $\begin{array}{l}\text { Pacific coastal } \\
\text { upwelling }\end{array}$ & ETS & $3-750$ & Packard et al., 2015 \\
\hline N Pacific & INT & $56-107$ & Martínez-García, 2017 \\
\hline Pacific & OUR & $0.05-27$ & Feely et al., 2004 \\
\hline SE Pacific & OUR & $5-55$ & Sonnerup et al., 2015 \\
\hline NE Pacific & OUR & $0.3-30$ & Sonnerup et al., 2013 \\
\hline Atlantic & OUR & $17 \pm 3$ & Stanley et al., 2012 \\
\hline
\end{tabular}

the imperative to maintain in situ oxygen concentrations during shipboard sample collection, manipulation and analysis remains a significant challenge (Garcia-Robledo et al., 2016).

\section{Apportionment to Microbial Group}

In addition to bulk measurements of respiration, an appreciation of the proportion of respiration attributable to bacterioplankton or zooplankton and between particle-attached or free-living bacterioplankton is important for accurate predictions and projections of carbon remineralization and thus deoxygenation and marine carbon storage in a changing environment. Unfortunately, such apportionment of respiration to constituent plankton functional groups is hampered by the lack of a direct method able to differentiate the respiration of any component group from that of the rest of the plankton community. The postincubation separation by filtration of a size class of the plankton community, coupled with the identification and enumeration of plankton within that size class, has become the pragmatic although imperfect field approach to infer the respiration of a particular group which dominates a particular size class. This is obviously problematic in environments where cells of the same size represent very different functional groups, for example, heterotrophic and autotrophic prokaryotes in the surface waters of oligotrophic gyres, but perhaps is less of a problem in coastal regions or in the mesopelagic.

The relative proportion of mesopelagic bacterioplankton and zooplankton respiration varies with euphotic zone productivity. Bacterioplankton respiration was 2- to 10-fold higher than zooplankton respiration at the oligotrophic ALOHA station in the North Pacific Subtropical Gyre, and up to fivefold higher at 
the mesotrophic station K2 in the subarctic Pacific (Steinberg et al., 2008). Giering et al. (2014) found bacterioplankton respiration to dominate $(70-92 \%)$ community respiration in the North Atlantic mesopelagic zone, while McDonnell et al. (2015) showed that the respiration rates of particle-associated microbes contributed $32-98 \%$ of the total respiration measured in situ at the Bermuda Atlantic Time-series Study site (BATS). Direct measurements of the oxygen consumption of microbes associated with phytodetrital aggregates collected using marine snow catchers in the northeast Atlantic, showed that the relative importance of particle-associated microbial respiration to the attenuation of particulate organic carbon (POC) increases from $\sim 8 \%$ in the upper mesopelagic $(36-128 \mathrm{~m})$ to $\sim 33 \%$ in the mid mesopelagic $(129-500 \mathrm{~m})$ as the rate of POC attenuation decreases (Belcher et al., 2016).

\section{Influence of Environmental Conditions}

Respiration rates vary in space and time depending on temperature, the quality and quantity of the organic substrate, availability of inorganic nutrients, and microbial community structure. Just like any other chemical reaction or metabolic rate, plankton respiration is related to temperature through an Arrhenius relationship. Mazuecos et al. (2015) derived mesopelagic respiration from oxygen consumption measurements and calculated a $\mathrm{Q}_{10}$ of 3.65 and an activation energy $\mathrm{E}_{\mathrm{a}}$ of $0.90 \mathrm{eV}$ for water temperatures between 8.7 and $14.9^{\circ} \mathrm{C}$. This compared well with the temperature relationship of previously published mesopelagic respiration data (average $\mathrm{Q}_{10}$ of 4.07 and $\mathrm{E}_{\mathrm{a}}$ of $0.98 \mathrm{eV}$ ), but is higher than the "optimal" $\mathrm{Q}_{10}$ values of between 1.5 and 2.6 of mesopelagic remineralization of particulate organic carbon derived from data-constrained modeling studies (DeVries and Weber, 2017; Laufkötter et al., 2017; Cram et al., 2018), and of activation energies determined for microbial respiration in surface waters $(\sim 0.58 \mathrm{eV}$ López-Urrutia and Móran, 2007; Yvon-Durocher et al., 2012).

Cell specific mesopelagic bacterioplankton respiration rates (Table 2) tend not to be correlated with temperature due to the $\sim 50$-fold variability in cell specific respiration rates $(0.1$ to 5 fmol C cell ${ }^{-1}$ day $^{-1}$; Baltar et al., 2009a,b) related to the lack of a strong relationship between cell abundance and cell activity (del Giorgio and Gasol, 2008). For example, Reinthaler et al. (2006) found a threefold difference in bacterioplankton cell specific respiration rates in deep water masses of the east and west $\mathrm{N}$ Atlantic, with a general increase with depth, and with rates in the oxygen minimum zones intermediate between those in the more oxygenated water masses above and below.

Experiments which mimic the increase in pressure experienced by surface dwelling bacterioplankton as they descend to the mesopelagic zone associated with particles, show that rates of organic matter degradation decrease with increasing pressure (Tamburini et al., 2013). However, bacterioplankton which are endemic to the mesopelagic, adapt to conditions of high pressure, low temperature and low substrate availability, such that measurements of bacterioplankton production made at atmospheric pressure on decompressed samples underestimate in situ mesopelagic activity (Tamburini et al., 2013). As far as
TABLE 2 | Mesopelagic cell specific respiration (fmol C cell ${ }^{-1}$ day $^{-1}$ ) derived from measurements of electron transport system activity (ETS) or dissolved oxygen consumption $\left(\Delta \mathrm{O}_{2}\right)$.

\begin{tabular}{|c|c|c|c|}
\hline Region & Sample type & $\begin{array}{c}\text { Cell specific } \\
\text { respiration (fmol } \\
\text { C cell }{ }^{-1} \text { day }^{-1} \text { ) }\end{array}$ & Reference \\
\hline $\begin{array}{l}\text { Louisiana Shelf, } \\
\text { United States }\end{array}$ & $<1 \mu \mathrm{m}, \Delta \mathrm{O}_{2}$ & $2.4-8.7$ & $\begin{array}{l}\text { Biddanda et al. } \\
1994\end{array}$ \\
\hline $\begin{array}{l}\text { Menai Strait, } \\
\text { United Kingdom }\end{array}$ & $<0.8 \mu \mathrm{m}, \Delta \mathrm{O}_{2}$ & $0.4-6.8$ & $\begin{array}{l}\text { Blight et al., } \\
1995\end{array}$ \\
\hline $\begin{array}{l}\text { Gulf of Mexico, } \\
\text { United States }\end{array}$ & $<0.8 \mu \mathrm{m}, \Delta \mathrm{O}_{2}$ & 0.39 & $\begin{array}{l}\text { Jørgensen } \\
\text { et al., } 1999\end{array}$ \\
\hline $\begin{array}{l}\text { Cardigan Bay, } \\
\text { United Kingdom }\end{array}$ & $\begin{array}{l}0.2-12 \mu \mathrm{m} \\
\Delta \mathrm{O}_{2}\end{array}$ & $4.28 \pm 1.12$ & $\begin{array}{l}\text { Mukhanov } \\
\text { et al., } 2003\end{array}$ \\
\hline North Sea & $<0.8 \mu \mathrm{m}, \Delta \mathrm{O}_{2}$ & $0.3-3.6$ & $\begin{array}{l}\text { Reinthaler } \\
\text { et al., } 2005\end{array}$ \\
\hline NW African coast & $\begin{array}{l}\text { Whole sample, } \\
\Delta \mathrm{O}_{2}\end{array}$ & $0.2-2.0$ & $\begin{array}{l}\text { Gasol et al., } \\
2009\end{array}$ \\
\hline $\begin{array}{l}\text { Temperate North } \\
\text { Atlantic }\end{array}$ & & & $\begin{array}{l}\text { Reinthaler } \\
\text { et al., } 2006\end{array}$ \\
\hline $100-135$ m & $<0.6 \mu \mathrm{m}, \Delta \mathrm{O}_{2}$ & Average 0.85 & \\
\hline $\begin{array}{l}402-725 \mathrm{~m}\left(\mathrm{O}_{2}\right. \\
\text { minimum) }\end{array}$ & $<0.6 \mu \mathrm{m}, \Delta \mathrm{O}_{2}$ & Average 1.67 & \\
\hline 1800-3000 m & $<0.6 \mu \mathrm{m}, \Delta \mathrm{O}_{2}$ & Average 2.74 & \\
\hline Southern Ocean & & & $\begin{array}{l}\text { Obernoster } \\
\text { et al., } 2008\end{array}$ \\
\hline $0-100 \mathrm{~m}$ & $<0.8 \mu \mathrm{m}, \Delta \mathrm{O}_{2}$ & $0.5-1.9$ & \\
\hline $1000-4500 \mathrm{~m}$ & $\begin{array}{l}\text { Whole sample, } \\
\Delta \mathrm{O}_{2}\end{array}$ & $0.23-6.9$ & \\
\hline $\begin{array}{l}\text { Subtropical North } \\
\text { Atlantic }\end{array}$ & & & $\begin{array}{l}\text { Baltar et al., } \\
2009 a\end{array}$ \\
\hline $100 \mathrm{~m}$ & $\begin{array}{l}\text { Whole sample, } \\
\text { ETS }\end{array}$ & $0.04-3.82$ & \\
\hline 200-1000 m & $\begin{array}{l}\text { Whole sample, } \\
\text { ETS }\end{array}$ & $0.12-5.23$ & \\
\hline $1000-5000 \mathrm{~m}$ & $\begin{array}{l}\text { Whole sample, } \\
\text { ETS }\end{array}$ & $0.43-7.66$ & \\
\hline $\begin{array}{l}\text { Subtropical North } \\
\text { Atlantic }\end{array}$ & & & $\begin{array}{l}\text { Baltar et al., } \\
\text { 2009b }\end{array}$ \\
\hline $100 \mathrm{~m}$ & $\begin{array}{l}\text { Whole sample, } \\
\text { ETS }\end{array}$ & $0.17-1.18$ & \\
\hline $200-1000 \mathrm{~m}$ & $\begin{array}{l}\text { Whole sample, } \\
\text { ETS }\end{array}$ & $0.14-2.88$ & \\
\hline $1800-4500 \mathrm{~m}$ & $\begin{array}{l}\text { Whole sample, } \\
\text { ETS }\end{array}$ & $0.23-6.90$ & \\
\hline
\end{tabular}

Adapted from Baltar et al. (2009b).

I am aware, measurements of mesopelagic bacterioplankton respiration have not yet been made at in situ pressures.

Nutrient addition experiments with oligotrophic and mesotrophic surface water plankton populations show increased plankton community and bacterioplankton respiration after addition of a mixture of glucose and amino acids (MartínezGarcía et al., 2013), and time series studies and data syntheses show significant correlations between bacterioplankton respiration and concentrations of dissolved organic carbon (Alonso-Sáez et al., 2008; Robinson, 2008). Bioavailability experiments with natural bacterioplankton communities and 
dissolved organic material harvested from cultures of four coastal diatoms under silicate and/or nitrate stress suggest that DOM remineralization and bacterioplankton growth efficiencies are influenced on time scales of a week by the nutrient stress under which the DOM is produced. However, on seasonal time scales, the diatom source species is more influential (Wear et al., 2015).

The interacting effect of increasing temperature and organic carbon supply on coastal bacterioplankton respiration and growth efficiencies has been studied recently in chemostats and turbidostats. In substrate limited conditions, growth efficiencies showed no trend with temperature, whereas under temperature limited, substrate replete conditions, bacterioplankton growth efficiencies increased with temperature (Maske et al., 2017). This contrasts with the meta-analysis of Rivkin and Legendre (2001) which showed a decrease in bacterioplankton growth efficiencies with increasing temperature.

In addition to the influence of nutrient availability and DOM composition, the bioavailability of DOM (and hence respiration rate) is also controlled by microbial community composition. Mesopelagic microbial communities in the eastern tropical South Pacific were able to utilize surface layer dissolved organic carbon which was recalcitrant to remineralization by surface microbial communities over time scales of 9-14 days (Letscher et al., 2015). Likewise, incubations of ambient seawater amended with $\mathrm{DO}^{13} \mathrm{C}$ substrates including defined monosaccharides and exudates and lysates from ${ }^{13} \mathrm{C}$-labeled Synechococcus cultures showed that each DOC substrate stimulated a different community growth response and a different rate of DOC removal (Nelson and Carlson, 2012). While Synechococcus exudates are incorporated by a wide diversity of bacterial taxa, defined monosaccharides and Synechococcus lysates were less bioavailable to ambient bacterioplankton.

\section{RESPIRATORY QUOTIENTS}

The relationship between the production of $\mathrm{CO}_{2}$ and the consumption of $\mathrm{O}_{2}$ during respiration is the respiratory quotient (RQ $\left.=\Delta \mathrm{CO}_{2} /-\Delta \mathrm{O}_{2}\right)$ and this varies depending on the stoichiometry of the organic substrate and the degree of oxidation or metabolic pathway used. Assuming complete oxidation, the RQ could range from 0.13 for lipid $\left(\mathrm{C}_{40} \mathrm{H}_{74} \mathrm{O}_{5}\right), 0.50$ for methane $\left(\mathrm{CH}_{4}\right), 0.67$ for saturated fatty acid $\left(-\mathrm{CH}_{2}-\right), 1.00$ for glucose $\left(\mathrm{C}_{6} \mathrm{H}_{12} \mathrm{O}_{6}\right), 1.24$ for nucleic acid $\left(\mathrm{C}_{1} \mathrm{H}_{1.3} \mathrm{O}_{0.7} \mathrm{~N}_{0.4} \mathrm{P}_{0.11}\right), 1.33$ for glycolic acid $\left(\mathrm{C}_{2} \mathrm{H}_{4} \mathrm{O}_{3}\right)$ and 4.00 for oxalic acid $\left(\mathrm{C}_{2} \mathrm{H}_{2} \mathrm{O}_{4}\right)$ (Rodrigues and Williams, 2001; Williams and del Giorgio, 2005; Berggren et al., 2011). Assuming the substrate is similar to the average composition of planktonic material, e.g., 65\% protein, $19 \%$ lipid, $16 \%$ carbohydrate, or the typical composition of a phytoplankton cell, e.g., 40\% protein, 40\% carbohydrate, $15 \%$ lipid, 5\% nucleic acid gives an RQ of 0.89 (Williams and del Giorgio, 2005). Quantifying the variability in RQ allows not only the production of $\mathrm{CO}_{2}$ to be calculated from dissolved oxygen consumption, but also reveals shifts in plankton physiology that are not evident from any other measurement. Culture studies with marine bacteria (Vibrio natriegens and Pseudomonas nautica) show that the respiratory quotient varies with physiological state, metabolic pathway and carbon source (acetate or pyruvate) (Berdalet et al., 1995; Roy et al., 1999; Romero-Kutzner et al., 2015).

A systematic field study of the RQs of freshwater bacterioplankton showed large variability (1.2 \pm 0.45$)$ with a significant negative correlation between RQ and in situ $\mathrm{O}_{2}$ concentration and $\mathrm{pH}$ and a significant positive correlation between $\mathrm{RQ}$ and in situ $\mathrm{pCO}_{2}$ (Berggren et al., 2011). Bacterioplankton RQs were low (average 0.81) in net autotrophic freshwater systems where reduced substrates derived from phytoplankton excretion are likely to dominate and higher (average 1.35) in net heterotrophic freshwater systems where oxidized substrates such as organic acids formed by photochemical processes could occur (Allesson et al., 2016). However, due to the low rates of oxygen consumption and $\mathrm{CO}_{2}$ production by marine plankton, and the precision of methods to measure changes in dissolved inorganic carbon (DIC; 1-2 mmol $\mathrm{m}^{-3}$ ), there has not been a systematic field study of the magnitude and variability of marine plankton RQs. Most studies of marine plankton respiration rely on measurements of dissolved oxygen consumption and assume a constant RQ of either 0.8 or 1.0 (e.g., Reinthaler et al., 2006; Nguyen et al., 2012; Teira et al., 2013), accepting that this introduces an error into the calculation of $\mathrm{CO}_{2}$ production, since the RQ is likely to vary with environmental conditions and substrate availability.

Field measurements of the concurrent consumption of oxygen $\left(-\Delta \mathrm{O}_{2}\right)$ and production of DIC $\left(\Delta \mathrm{CO}_{2}\right)$ of seawater samples incubated in the dark for $24 \mathrm{~h}$, can be used to derive an apparent respiratory quotient (ARQ; Angert et al., 2015). This is the integrative effect of not only the aerobic respiration of bacterio, archaeo-, phyto-, and microzooplankton in the sample, but also all the other microbial metabolic processes which use or produce $\mathrm{O}_{2}$ or $\mathrm{CO}_{2}$, including nitrification (uptake of $\mathrm{O}_{2}$ without production of $\mathrm{CO}_{2}$ ), production of methane from acetate or methylamines (production of $\mathrm{CO}_{2}$ without utilization of $\mathrm{O}_{2}$ ), and production and dissolution of calcium carbonate (production or uptake of $\mathrm{CO}_{2}$ without affecting $\mathrm{O}_{2}$, respectively). The range of ARQs obtained from multiple field studies (Robertson, 1989; Wood, 1992; Robinson et al., 1999, 2002a,b; Sondergaard et al., 2000; Lefèvre et al., 2008 in Figure 2) spans the range of RQs calculated from the stoichiometry of potential substrates for microbial aerobic respiration with a median of 0.88 and an average of $1.11 \pm 0.76(n=149)$. There is some indication that higher ARQs occur in waters above the oxygen minimum zone in the Arabian Sea (Robinson and Williams, 1999) and lower ARQs occur during blooms of the coccolithophore Emiliania huxleyi (Holligan et al., 1993; Robertson et al., 1994). Until a more sensitive method is developed to measure $\mathrm{CO}_{2}$ or DIC and a systematic study undertaken, derivation of $\mathrm{CO}_{2}$ production from $\mathrm{O}_{2}$ consumption will depend on using a constant $\Delta \mathrm{CO}_{2} /-\Delta \mathrm{O}_{2}$ ratio, accepting the potential $20-40 \%$ error (Reinthaler et al., 2006).

An apparent respiratory quotient integrated over longer time and larger space scales can also be derived from the relationship between DIC and AOU within a particular water mass. Measurements and models of the DIC:AOU ratio suggest a range between 0.51 and 0.85 depending on the composition 


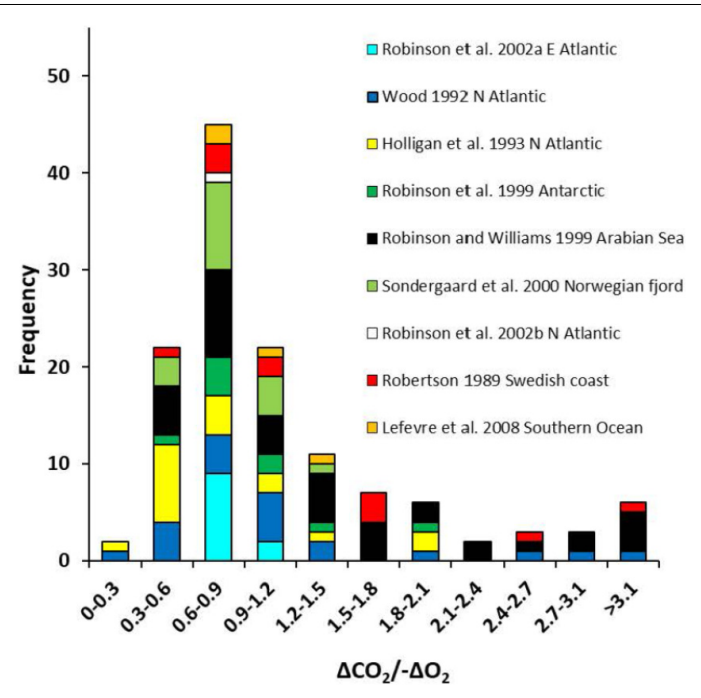

FIGURE 2 | Frequency histogram of apparent respiratory quotients (the ratio of oxygen consumption to production of dissolved inorganic carbon).

of the organic material being degraded - lower ratios are associated with the remineralization of labile and nitrogen-rich organic matter, higher ratios with remineralization of more recalcitrant organic matter (Thomas, 2002; Paulmier et al., 2009) - the combination of biogeochemical processes (e.g., respiration, nitrification, denitrification, anammox) occurring, and the history of the source water in terms of the different sensitivities of $\mathrm{O}_{2}$ and DIC to changes in temperature and the different time scales of $\mathrm{O}_{2}$ and $\mathrm{CO}_{2}$ air-sea exchange (Anderson and Sarmiento, 1994; Thomas, 2002; Loucaides et al., 2012).

The ARQs of waters within oxygen minimum zones (and corresponding carbon maximum zones; Paulmier et al., 2011) vary between 0.6 and 1.5. Paulmier et al. (2011) determined the ARQ of waters in the shallow, very intense oxycline of Chilean coastal waters to be $1.1 \pm 0.3$, potentially due to relatively higher rates of DIC production from more complete degradation of highly carbonated organic matter (Van Mooy et al., 2002; Paulmier et al., 2011).

\section{SENSITIVITY TO DECREASING OXYGEN AND INCREASING CARBON DIOXIDE}

Since the enzymes used during aerobic respiration require oxygen, at some level the rate of respiration will be directly sensitive to the ambient concentration of dissolved oxygen. In addition, dissolved oxygen concentration is a major determinant of microbial abundance and diversity (Wright et al., 2012) and will therefore indirectly affect the rate of respiration and other biogeochemical processes.

Hartnett et al. (1998), originally noted the strong negative relationship between sedimentary organic carbon preservation and length of exposure to oxygen, while Devol and Hartnett (2001) showed the influence of dissolved oxygen on midwater remineralisation. Calculated attenuation rates of particulate organic carbon flux for the oxic water column of the continental margin off Washington State were significantly higher than the attenuation rates calculated for the oxygen-deficient continental margin off northwest Mexico. A synthesis of attenuation length scale estimated from export flux and deep sediment trap data (Henson et al., 2012) shows clearly that mesopelagic remineralization is much reduced at low concentrations of dissolved oxygen (Sanders et al., 2016). Laufkötter et al. (2017) compiled particulate organic carbon flux measurements from 19 globally distributed sites and found that the attenuation of the flux of particulate organic matter depends on oxygen described by a half-saturation constant between 4 and $12 \mu \mathrm{mol} \mathrm{L}^{-1}$. However, as well as any direct effect of reduced dissolved oxygen on aerobic microbial respiration, these attenuation rates will also include the indirect effect of reduced dissolved oxygen decreasing the depth of zooplankton diel vertical migration and so fragmentation, repackaging and respiration of organic carbon mediated by zooplankton (Cavan et al., 2016).

Due to the technical challenges of both measuring and maintaining extremely low oxygen concentrations, there are relatively few determinations of the oxygen sensitivity of aerobic respiration in low oxygen waters. Garcia-Robledo et al. (2016), using LUMOS optodes, found no apparent change in oxygen consumption rates at oxygen concentrations between $\sim 1.0$ and $10 \mu \mathrm{mol} \mathrm{L} \mathrm{L}^{-1}$ in waters collected from the oxygen minimum zones of the eastern tropical Pacific Ocean and derived an apparent half saturation constant of $391 \mathrm{nmol} \mathrm{O}_{2} \mathrm{~L}^{-1}$. This agrees with a previous study using STOX microsensors which on average showed little oxygen dependence above oxygen concentrations of $500 \mathrm{nmol} \mathrm{L}^{-1}$ (Tiano et al., 2014). However, Kalvelage et al. (2015) showed an increase in aerobic

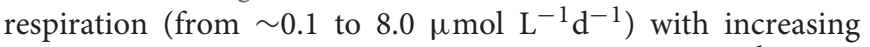
ambient $\mathrm{O}_{2}$ concentrations (from $\sim 1$ to $20 \mu \mathrm{mol} \mathrm{L} \mathrm{L}^{-1}$ ). This change in aerobic respiration is likely associated with changing community structure. Beman and Carolan (2013) sampled across oxygen gradients in the OMZ of the Gulf of California using pyrosequencing of $16 \mathrm{~S}$ rRNA to show maximum values of bacterial richness on the edge of the $\mathrm{OMZ}$ where availability of oxidants and reductants contribute to functional and taxonomic diversity. Predicting the biochemical response of the microbial community to fluctuations in oxygen concentrations is extremely difficult, as both aerobic and anaerobic processes occur simultaneously, even in waters with undetectable oxygen concentrations (Bertagnolli and Stewart, 2018).

Since decreasing $\mathrm{O}_{2}$ due to respiration will always be coupled with increasing $\mathrm{CO}_{2}$, which leads to ocean acidification through decreasing $\mathrm{pH}$ and carbonate ion concentration, it is relevant to assess the positive or negative feedbacks associated with the direct and indirect effects of increasing $\mathrm{CO}_{2}$ on plankton respiration. Many bacterial enzymatic processes involved in the utilization of organic compounds increase with increasing $\mathrm{CO}_{2}$, or decreasing pH (e.g., Grossart et al., 2006; Piontek et al., 2010; Mass et al., 2013). Bunse et al. (2016) demonstrated upregulation of respiratory proton pumps at elevated $\mathrm{CO}_{2}$ concentrations, presumably in order to export protons that invade the bacterioplankton cell as a result of low $\mathrm{pH}$. Such proton exporting mechanisms are inherently energy demanding, 
so that bacterioplankton would need to allocate more energy to cell maintenance instead of growth, implying a decrease in bacterial growth efficiency with increasing $\mathrm{CO}_{2}$ (Bunse et al., 2016). This is consistent with measurements of the direct effect of increased $\mathrm{CO}_{2}$ on bacterioplankton metabolism, revealing systematically greater cell-specific respiration in elevated $\mathrm{CO}_{2}$ (James et al., 2017). This latter study also suggested that high $\mathrm{CO}_{2}$ conditions may increase the ability of bacterioplankton to consume DOC, but with reduced growth efficiencies, leading to decreased storage of DOC.

Indirect effects of increased $\mathrm{CO}_{2}$ on bacterioplankton respiration include increased respiration due to (1) the increased quantity and quality of phytoplankton derived particulate and dissolved organic carbon and/or (2) reduced calcium carbonate ballast enabling greater bacterial access to associated organic material. Mesocosm experiments in a range of nutrient regimes and plankton communities show equivocal results. Some show that bacteria benefitted both directly through enhanced enzymatic hydrolysis of organic matter and indirectly through increased availability of phytoplankton derived organic substrate (Grossart et al., 2006; Piontek et al., 2010), and that copepods increased their respiration rate at elevated $\mathrm{CO}_{2}$ concentrations ( $\mathrm{Li}$ and Gao, 2012). However, recent mesocosm and microcosm studies in an Arctic fjord, the Mediterranean Sea and the subtropical North Atlantic Ocean found no significant relationship between bacterioplankton or plankton community respiration and $\mathrm{CO}_{2}$ concentrations (Motegi et al., 2013; Tanaka et al., 2013; Mercado et al., 2014; Maugendre et al., 2017; Filella et al., 2018), and Spilling et al. (2016) found a decrease in plankton community respiration at elevated $\mathrm{CO}_{2}$ levels during a mesocosm experiment in the Baltic Sea.

As far as I am aware there have been no $\mathrm{CO}_{2}$ manipulation studies of mesopelagic microbial communities or studies of the cumulative (additive, synergistic or antagonistic) effect of the combination of decreasing dissolved oxygen and increasing $\mathrm{CO}_{2}$ on environmental genomics and plankton respiration, as have been undertaken for metabolic rates of invertebrate and vertebrate marine organisms (Gobler and Baumann, 2016).

\section{KNOWN UNKNOWNS AND RECOMMENDATIONS FOR FUTURE RESEARCH}

Current models do not reproduce the observed patterns of changes in dissolved oxygen, they underestimate the interannual to decadal variability in dissolved oxygen and they simulate only half of the oceanic oxygen loss inferred from observations (Oschlies et al., 2018). Increased in situ observations and quantitative mechanistic understanding of the influence of both physical and biological processes on dissolved oxygen changes are therefore required to develop and verify these numerical models. In particular, since these models account for the major physical and chemical processes involved in deoxygenation, but do not include some of the microbial processes and feedbacks discussed here, it is relevant to investigate whether including these microbiological processes would account for the additional decrease in oxygen needed to match the model outputs with the observations.

The major biological process influencing a decline in dissolved oxygen concentration is plankton respiration. Hence improved mechanistic understanding of the drivers influencing the variability of respiration, particularly those that are climate sensitive, or currently not represented in numerical models, is required. Examples would include the influence of changing inorganic nutrient concentrations and stoichiometry on plankton community structure including the proportion of respiration attributable to bacterioplankton or vertically migrating zooplankton and the size distribution and composition of exported particles, changes in the respiratory quotient, the interacting effects of increasing $\mathrm{CO}_{2}$ and decreasing $\mathrm{O}_{2}$ on bacterioplankton respiration, and the influence of warming and nutrient stoichiometry on the bacterial utilization of previously recalcitrant dissolved organic carbon (Jiao et al., 2010, 2014; Zhang et al., 2018). On a broader scale, this complex wicked problem also requires an appreciation of the potential feedbacks between primary production, nitrogen cycling, organic matter flux and oxygen consumption (Canfield, 2006; Boyle et al., 2013; Bristow et al., 2016). At the microbial scale, representation of symbiotic metabolic interactions (Wright et al., 2012), including the potential for cryptic oxygen cycling to occur within otherwise anoxic zones (Garcia-Robledo et al., 2017) is required.

A dedicated longtime and large spatial scale observational program is required, linked to a numerical modeling framework (Oschlies et al., 2018), and within which targeted manipulation experiments could take place. The observational program would include a range of methods for determining plankton respiration from the individual organism to the oceanographic region, including those already established (e.g., in vitro $\mathrm{O}_{2}$ consumption, electron transport system activity, ${ }^{14} \mathrm{CO}_{2}$ production, AOU) and those currently in development (e.g., fluorescence, in situ respirometry, and derivation from optode measurements on moorings, gliders and biogeochemical Argo floats ${ }^{1}$ ), measured alongside the plankton community structure and organic/inorganic nutrient regime (e.g., Honjo et al., 2014; Collins et al., 2018). Metagenomic analysis coupled with trace chemical assays and isotope tracer experiments should be incorporated into the observational program to reveal the detail of low oxygen metabolic pathways (Bertagnolli and Stewart, 2018). In addition, established multidisciplinary time series and global surveys (e.g., OceanSITES ${ }^{2}$ and GO-SHIP ${ }^{3}$ ) should begin to place as much emphasis on determining the plankton respiratory processes which utilize dissolved oxygen and convert organic carbon to $\mathrm{CO}_{2}$, as they currently do on the autotrophic processes which produce dissolved oxygen and convert $\mathrm{CO}_{2}$ to particulate and dissolved organic carbon. An implementation plan to specifically quantify the capacity for marine carbon storage through recalcitrant dissolved organic carbon (the microbial carbon pump), and the potential reduction in this capacity due to global change, leading to a positive

\footnotetext{
${ }^{1}$ http://www.argo.ucsd.edu/

${ }^{2}$ http://www.oceansites.org/index.html

${ }^{3}$ http://www.go-ship.org/index.html
} 
feedback of increased oxygen consumption and $\mathrm{CO}_{2}$ production, has recently been proposed (Robinson et al., 2018).

Isolation and cultivation of a greater number of microbes from low oxygen waters will help quantify the oxygen thresholds constraining chemical fluxes and identify the enzymes responsible (Bertagnolli and Stewart, 2018). A suite of single species and natural plankton community micro-, meso- and macro-cosm manipulation experiments should be embedded within the observational and modeling framework, specifically to confirm or refute proposed biological mechanisms of increasing ocean deoxygenation and the interacting effects of increasing $\mathrm{CO}_{2}$ and decreasing $\mathrm{O}_{2}$ on plankton metabolism (Figure 1). Since ocean deoxygenation is linked mechanistically to other ocean stressors (or drivers) including warming, acidification and nutrient availability and stoichiometry, these manipulation experiments will need to be multiple stressor experiments and follow appropriate best practice in design, implementation and statistical analysis (Riebesell and Gattuso, 2014; Boyd et al., 2016, 2018). The Scientific Committee on Oceanic Research (SCOR) working group 149 has recently released an open access decision support tool https://scor149-ocean.com/ decision-support-tool/ to aid in design and interpretation of multiple stressor experiments, and a Multiple Driver Best Practice Guide will be launched in 2019.

The predictions and projections of the distribution and extent of ocean deoxygenation and the cumulative effects of other drivers of global change afforded by the observational verification of numerical models, need to also extend to predictions of the consequences of ocean deoxygenation on the ecosystem services and human livelihoods and welfare provided by the ocean (Breitburg et al., 2018). This aligns with the scientific objectives of the Integrated Marine Biosphere Research project (IMBeR) to incorporate understanding of the drivers and consequences of global change on marine ecosystems and human societies at multiple scales into models to project and predict future states (Hofmann and The IMBeR Scientific Steering Committee, 2016), and the Intergovernmental Oceanographic Commission (IOC) of UNESCO sponsored expert group, the Global Ocean Oxygen Network $\mathrm{GO}_{2} \mathrm{NE}^{4}$ which aims to improve ocean oxygen observation systems, identify and fill knowledge gaps, build

${ }^{4} \mathrm{http} / / / \mathrm{www} \cdot$ unesco.org/new/en/natural-sciences/ioc-oceans/sections-and-

programmes/ocean-sciences/global-ocean- oxygen-network/

\section{REFERENCES}

Aguiar-González, B., Packard, T. T., Berdalet, E., Roy, S., and Gómez, M. (2012). Respiration predicted from an Enzyme Kinetic Model and the Metabolic Theory of Ecology in two species of marine bacteria. J. Exp. Mar. Biol. Ecol. 412, 1-12. doi: 10.1016/j.jembe.2011.09.018

Allesson, L., Ström, L., and Berggren, M. (2016). Impact of photochemical processing of DOC on the bacterioplankton respiratory quotient in aquatic ecosystems. Geophys. Res. Lett. 43, 7538-7545. doi: 10.1002/2016GL06 9621

Alonso-Sáez, L., Vázquez-Domínguez, E., Cardelús, C., Pinhassi, J., Montserrat Sala, M., Lekunberri, I., et al. (2008). Factors controlling the year-round variability in carbon flux through bacteria in a coastal marine system. Ecosystems 11, 397-409. doi: 10.1007/s10021-0089129-0 capacity, and provide scientific advice to policy makers. $\mathrm{GO}_{2} \mathrm{NE}$ also maintains the news site www.ocean-oxygen.org for scientists, stakeholders and the interested public.

Only through international co-ordination and collaboration will we be able to quantify the environmental, physiological and ecological drivers of variability in plankton respiration contributing to ocean deoxygenation, and hence predict and project the cumulative effect of ocean deoxygenation and other global change drivers on marine ecosystems and human societies.

\section{AUTHOR CONTRIBUTIONS}

CR conceived and wrote the article.

\section{FUNDING}

This study was supported by funds from The Leverhulme Trust (Grant RPG-2017-089 awarded to CR) and the Natural Environment Research Council (NERC) of the United Kingdom (Grants NE/R000956/1 and NE/K00168X/1 awarded to CR). I gratefully acknowledge financial support from The Royal Society (United Kingdom), EurOceans and the Integrated Marine Biogeochemistry and Ecosystem Research (IMBER; http://www. imber.info/) project sponsored workshops on "Ocean ventilation and deoxygenation in a warming world" in September 2016 and on "Ocean deoxygenation and implications for marine biogeochemical cycles and ecosystems" in October 2011 which provided financial support for me to attend.

\section{ACKNOWLEDGMENTS}

This study arose from invitations to present at the two workshops described above. The manuscript benefits from discussions with Dr. Elena García-Martin (University of East Anglia, United Kingdom), the OCEANic release of Greenhouse gASes under pressure from multiple stressors (OCEAN-GASP) team led by Dr. Andrew Rees (Plymouth Marine Laboratory, United Kingdom), and the editorial and reviewing team at Frontiers.

Anderson, L. A., and Sarmiento, J. L. (1994). Redfield ratios of remineralization determined by nutrient data analysis. Glob. Biogeochem. Cycles 8, 65-80. doi: 10.1029/93GB03318

Angert, A., Yakir, D., Rodeghiero, M., Preisler, Y., Davidson, E. A., and Weiner, T. (2015). Using $\mathrm{O}_{2}$ to study the relationships between soil $\mathrm{CO}_{2}$ efflux and soil respiration. Biogeosciences 12, 2089-2099. doi: 10.5194/bg-12-20892015

Arístegui, J., Duarte, C. M., Gasol, J. M., and Alonso-Sáez, L. (2005). Active mesopelagic prokaryotes support high respiration in the subtropical northeast Atlantic Ocean. Geophys. Res. Lett. 32:L03608. doi: 10.1029/2004GL021863

Arístegui, J., Gasol, J. M., Duarte, C. M., and Herndl, G. J. (2009). Microbial oceanography of the dark ocean's pelagic realm. Limnol. Oceanogr. 54, 15011529. doi: 10.4319/lo.2009.54.5.1501

Arístegui, J., Agustí, S., and Duarte, C. M. (2003). Respiration in the dark ocean. Geophys. Res. Lett. 30:1041. doi: 10.1029/2002GL016227 
Baltar, F., Arístegui, J., Gasol, J. M., and Herndl, G. J. (2010). Prokaryotic carbon utilization in the dark ocean: growth efficiency, leucine-to-carbon conversion factors, and their relation. Aquat. Microb. Ecol. 60, 227-232. doi: 10.3354/ ame01422

Baltar, F., Arístegui, J., Gasol, J. M., Sintes, E., and Herndl, G. J. (2009a). Evidence of prokaryotic metabolism on suspended particulate organic matter in the dark waters of the subtropical North Atlantic. Limnol. Oceanogr. 54, 182-193. doi: 10.4319/lo.2009.54.1.0182

Baltar, F., Arístegui, J., Sintes, E., van Aken, H. M., Gasol, J. M., and Herndl, G. J. (2009b). Prokaryotic extracellular enzymatic activity in relation to biomass production and respiration in the meso-and bathypelagic waters of the (sub)tropical Atlantic. Environ. Microbiol. 11, 1998-2014. doi: 10.1111/j.14622920.2009.01922.x

Barker, S., Higgins, J. A., and Elderfield, H. (2003). The future of the carbon cycle: review, calcification response, ballast and feedback on atmospheric $\mathrm{CO}_{2}$. Philos. Trans. R. Soc. A Math. Phys. Eng. Sci. 361, 1977-1998; discussion 1998-1999. doi: $10.1098 /$ rsta.2003.1238

Belcher, A., Iversen, M., Giering, S., Riou, V., Henson, S. A., Berline, L., et al. (2016). Depth-resolved particle-associated microbial respiration in the northeast Atlantic. Biogeosciences 13, 4927-4943. doi: 10.5194/bg-13-49272016

Beman, J. M., and Carolan, M. T. (2013). Deoxygenation alters bacterial diversity and community composition in the ocean's largest oxygen minimum zone. Nat. Commun. 4:2705. doi: 10.1038/ncomms3705

Berdalet, E., Packard, T., Lagacé, B., Roy, S., St-Amand, L., and Gagné, J.-P. (1995). $\mathrm{CO}_{2}$ production, $\mathrm{O}_{2}$ consumption and isocitrate dehydrogenase in the marine bacterium Vibrio natriegens. Aquat. Microb. Ecol. 9, 211-217. doi: 10.3354/ ame009211

Berggren, M., Lapierre, J.-F., and del Giorgio, P. A. (2011). Magnitude and regulation of bacterioplankton respiratory quotient across freshwater environmental gradients. ISME J. 6, 984-993. doi: 10.1038/ismej.2011.157

Bertagnolli, A. D., and Stewart, F. J. (2018). Microbial niches in marine oxygen minimum zones. Nat. Rev. Microbiol. 16, 723-729. doi: 10.1038/s41579-0180087-z

Biddanda, B., Opsahl, S., and Benner, R. (1994). Plankton respiration and carbon flux through bacterioplankton on the Louisiana shelf. Limnol. Oceanogr. 39, 1259-1275. doi: 10.4319/lo.1994.39.6.1259

Blight, S. P., Bentley, T. L., Lefevre, D., Robinson, C., Rodrigues, R., Rowlands, J., et al. (1995). Phasing of autotrophic and heterotrophic plankton metabolism in a temperate coastal ecosystem. Mar. Ecol. Prog. Ser. 128, 61-75. doi: 10.3354/ meps 128061

Bopp, L., Le Quéré, C., Heimann, M., Manning, A. C., and Monfray, P. (2002). Climate-induced oceanic oxygen fluxes: implications for the contemporary carbon budget. Glob. Biogeochem. Cycles 16, 6-1-6-13. doi: 10.1029/ 2001GB001445

Boyd, P. W., Collins, S., Dupont, S., Fabricius, K., Gattuso, J.-P., Havenhand, J., et al. (2018). Experimental strategies to assess the biological ramifications of multiple drivers of global ocean change - A review. Glob. Change Biol. 24, 2239-2261. doi: 10.1111/gcb.14102

Boyd, P. W., Dillingham, P. W., McGraw, C. M., Armstrong, E. A., Cornwall, C. E., Feng, Y.-Y., et al. (2016). Physiological responses of a Southern Ocean diatom to complex future ocean conditions. Nat. Clim. Chang. 6, 207-216. doi: $10.1038 /$ nclimate2811

Boyle, R. A., Clark, J. R., Poulton, S. W., Shields-Zhou, G., Canfield, D. E., and Lenton, T. M. (2013). Nitrogen cycle feedbacks as a control on euxinia in the mid-Proterozoic ocean. Nat. Commun. 4:1533. doi: 10.1038/ ncomms 2511

Brandt, P., Bange, H. W., Banyte, D., Dengler, M., Didwischus, S.-H., Fischer, T., et al. (2015). On the role of circulation and mixing in the ventilation of oxygen minimum zones with a focus on the eastern tropical North Atlantic. Biogeosciences 12, 489-512. doi: 10.5194/bg-12-489-2015

Breitburg, D., Levin, L. A., Oschlies, A., Grégoire, M., Chavez, F. P., Conley, D. J., et al. (2018). Declining oxygen in the global ocean and coastal waters. Science 359:eaam7240. doi: 10.1126/science.aam7240

Brewer, P. G., and Peltzer, E. T. (2009). Limits to marine life. Science 324, 347-348. doi: $10.1126 /$ science. 1170756

Bristow, L. A., Callbeck, C. M., Larsen, M., Altabet, M. A., Dekaezemacker, J., Forth, M., et al. (2016). N2 production rates limited by nitrite availability in the Bay of Bengal oxygen minimum zone. Nat. Geosci. 10, 24-29. doi: 10.1038/ NGEO2847

Bunse, C., Lundin, D., Karlsson, C. M. G., Akram, N., Vila-Costa, M., Palovaara, J., et al. (2016). Response of marine bacterioplankton $\mathrm{pH}$ homeostasis gene expression to elevated $\mathrm{CO}_{2}$. Nat. Clim. Chang. 6, 483-487. doi: 10.1038/ NCLIMATE2914

Canfield, D. E. (2006). Models of oxic respiration, denitrification and sulfate reduction in zones of coastal upwelling. Geochim. Cosmochim. Acta 70, 57535765. doi: 10.1016/j.gca.2006.07.023

Cavan, E. L., Trimmer, M., Shelley, F., and Sanders, R. (2016). Remineralization of particulate organic carbon in an ocean oxygen minimum zone. Nat. Commun. 8:14847. doi: $10.1038 /$ ncomms 14847

Collins, J. R., Fucile, P. D., McDonald, G., Ossolinski, J. E., Keil, R. G., Valdes, J. R., et al. (2018). An autonomous, in situ light-dark bottle device for determining community respiration and net community production. Limnol. Oceanogr. Methods 16, 323-338. doi: 10.1002/lom3.10247

Cram, J. A., Weber, T., Leung, S. W., McDonnell, A. M. P., Liang, J.-H., and Deutsch, C. (2018). The role of particle size, ballast, temperature, and oxygen in the sinking flux to the deep sea. Glob. Biogeochem. Cycles 32, 858-876. doi: 10.1029/2017GB005710

del Giorgio, P. A., and Duarte, C. M. (2002). Respiration in the open ocean. Nature 420, 379-384. doi: 10.1038/nature01165

del Giorgio, P. A., and Gasol, J. M. (2008). "Physiological structure and single-cell activity in marine bacterioplankton," in Microbial Ecology of the Oceans, 2nd Edn, ed. D. L. Kirchman (Hoboken, NJ: John Wiley \& Sons, Inc).

Deutsch, C., Berelson, W., Thunell, R., Weber, T., Tems, C., and McManus, J. (2014). Centennial changes in North Pacific anoxia linked to tropical trade winds. Science 345, 665-668. doi: 10.1126/science.1252332

Deutsch, C., Brix, H., Ito, T., Frenzel, H., and Thompson, L. (2011). Climate-forced variability of Ocean Hypoxia. Science 333, 336-339. doi: 0.1126/science.1202422

Devol, A. H., and Hartnett, H. E. (2001). Role of oxygen-deficient zone in transfer of organic carbon to the deep ocean. Limnol. Oceanogr. 46, 1684-1690. doi: 10.4319/lo.2001.46.7.1684

DeVries, T., and Weber, T. (2017). The export and fate of organic matter in the ocean: new constraints from combining satellite and oceanographic tracer observations. Glob. Biogeochem. Cycles 31, 535-555. doi: 10.1002/ 2016GB005551

Diaz, R. J., and Rosenberg, R. (2008). Spreading dead zones and consequences for marine ecosystems. Science 321, 926-929. doi: 10.1126/science.1156401

Duteil, O., Koeve, W., Oschlies, A., Bianchi, D., Galbraith, E., Kriest, I., et al. (2013). A novel estimate of ocean oxygen utilization points to a reduced rate of respiration in the ocean interior. Biogeosciences 10, 7723-7738. doi: 10.5194/ bg-10-7723-2013

Engel, A., Delille, B., Jacquet, S., Riebesell, U., Rochelle-Newall, E., Terbrüggen, A., et al. (2004). Transparent exopolymer particles and dissolved organic carbon production by Emiliania huxleyi exposed to different $\mathrm{CO}_{2}$ concentrations: a mesocosm experiment. Aquat. Microb. Ecol. 34, 93-104. doi: 10.3354/ ame034093

Feely, R. A., Sabine, C. L., Schlitzer, R., Bullister, J. L., Mecking, S., and Greeley, D. (2004). Oxygen utilization and organic carbon remineralization in the upper water column of the Pacific Ocean. J. Oceanogr. 60, 45-52. doi: 10.1023/B: JOCE.0000038317.01279.aa

Fernández-Castro, B., Arístegui, J., Anderson, L., Montero, M. F., HernándezLeón, S., Marañón, E., et al. (2016). Mesopelagic respiration near the ESTOC (European Station for Time-Series in the Ocean, $15.5^{\circ} \mathrm{W}, 29.1^{\circ} \mathrm{N}$ ) site inferred from a tracer conservation model. Deep Sea Res. I Oceanogr. Res. Pap. 115, 63-73. doi: 10.1016/j.dsr.2016.05.010

Filella, A., Baños, I., Montero, M. F., Hernández-Hernández, N., RodriguezSantos, A., Ludwig, A., et al. (2018). Plankton community respiration and ETS activity under variable $\mathrm{CO}_{2}$ and nutrient fertilization during a mesocosm study in the Subtropical North Atlantic. Front. Mar. Sci. 5:310. doi: 10.3389/fmars 2018.00310

Garcia-Robledo, E., Borisov, S., Klimant, I., and Revsbech, N. P. (2016). Determination of respiration rates in water with sub-micromolar oxygen concentrations. Front. Mar. Sci. 3:244. doi: 10.3389/fmars.2016.00244

Garcia-Robledo, E., Padilla, C. C., Aldunate, M., Stewart, F. J., Ulloa, O., Paulmier, A., et al. (2017). Cryptic oxygen cycling in anoxic marine zones. Proc. Natl. Acad. Sci. U.S.A. 114, 8319-8324. doi: 10.1073/pnas.1619844114 
Gasol, J. M., Alonso-Sáez, L., Vaqué, D., Baltar, F., Calleja, M. L., Duarte, C. M., et al. (2009). Mesopelagic prokaryotic bulk and single-cell heterotrophic activity and community composition in the NW Africa-Canary Islands coastal-transition zone. Prog. Oceanogr. 83, 189-196. doi: 10.1016/j.pocean.2009.07.014

Giering, S. L. C., Sanders, R., Lampitt, R. S., Anderson, T. R., Tamburini, C., Boutrif, M., et al. (2014). Reconciliation of the carbon budget in the ocean's twilight zone. Nature 507, 480-483. doi: 10.1038/nature13123

Gobler, C. J., and Baumann, H. (2016). Hypoxia and acidification in ocean ecosystems: coupled dynamics and effects on marine life. Biol. Lett. 12:20150976. doi: 10.1098/rsbl.2015.0976

Grossart, H.-P., Allgaier, M., Passow, U., and Riebesell, U. (2006). Testing the effect of $\mathrm{CO}_{2}$ concentration on the dynamics of marine heterotrophic bacterioplankton. Limnol. Oceanogr. 51, 1-11. doi: 10.4319/lo.2006.51.1.0001

Gruber, N. (2011). Warming up, turning sour, losing breath: ocean biogeochemistry under global change. Philos. Trans. A Math. Phys. Eng. Sci. 369, 1980-1996. doi: 10.1098/rsta.2011.0003

Guidi, L., Legendre, L., Reygondeau, G., Uitz, J., Stemmann, L., and Henson, S. A. (2015). A new look at ocean carbon remineralization for estimating deepwater sequestration. Glob. Biogeochem. Cycles 29, 1044-1059. doi: 10.1002/ 2014GB005063

Hartnett, H. E., Kell, R. G., Hedges, J. I., and Devol, A. H. (1998). Influence of oxygen exposure time on organic carbon preservation in continental margin sediments. Nature 391, 572-574. doi: 10.1038/35351

Henson, S. A., Beaulieu, C., Ilyina, T., John, J. G., Long, M., Seferian, R., et al. (2017). Rapid emergence of climate change in environmental drivers of marine ecosystems. Nat. Commun. 8:14682. doi: 10.1038/ncomms14682

Henson, S. A., Sanders, R., and Madsen, E. (2012). Global patterns in efficiency of particulate organic carbon export and transfer to the deep ocean. Glob. Biogeochem. Cycles 26:GB1028. doi: 10.1029/2011GB004099

Hill, P. G., Warwick, P. E., and Zubkov, M. V. (2013). Low microbial respiration of leucine at ambient oceanic concentration in the mixed layer of the central Atlantic Ocean. Limnol. Oceanogr. 58, 1597-1604. doi: 10.4319/lo.2013.58.5. 1597

Hofmann, E. E., and The IMBeR Scientific Steering Committee (2016). IMBeR 2016-2025: Science Plan and Implementation Strategy. Bergen: IMBeR International Project Office.

Holligan, P. M., Fernández, E., Aiken, J., Balch, W. M., Boyd, P., Burkill, P. H., et al. (1993). A biogeochemical study of the coccolithophore, Emiliania huxleyi, in the North Atlantic. Glob. Biogeochem. Cycles 7, 879-900. doi: 10.1029/ 93GB01731

Holtappels, M., Tiano, L., Kalvelage, T., Lavik, G., Revsbech, N. P., and Kuypers, M. M. M. (2014). Aquatic respiration rate measurements at low oxygen concentrations. PLoS One 9:e89369. doi: 10.1371/journal.pone.0089369

Honjo, S., Eglinton, T. I., Taylor, C. D., Ulmer, K. M., Sievert, S. M., Bracher, A., et al. (2014). Understanding the role of the biological pump in the global carbon cycle: an imperative for ocean science. Oceanography 27, 10-16. doi: 10.5670/oceanog.2014.78

Ito, T., Nenes, A., Johnson, M. S., Meskhidze, N., and Deutsch, C. (2016). Acceleration of oxygen decline in the tropical Pacific over the past decades by aerosol pollutants. Nat. Geosci. 9, 443-447. doi: 10.1038/NGEO2717

James, A. K., Passow, U., Brzezinski, M. A., Parsons, R. J., Trapani, J. N., and Carlson, C. A. (2017). Elevated $\mathrm{pCO}_{2}$ enhances bacterioplankton removal of organic carbon. PLoS One 12:e0173145. doi: 10.1371/journal.pone.0173145

Jenkins, W. J. (1987). $3 \mathrm{H}$ and $3 \mathrm{He}$ in the Beta Triangle: observations of gyre ventilation and oxygen utilization rates. J. Phys. Oceanogr. 17, 763-783. doi: 10.1175/1520-0485(1987)017<0763:AITBTO>2.0.CO;2

Jiao, N., Herndl, G. J., Hansell, D. A., Benner, R., Kattner, G., Wilhelm, S. W., et al. (2010). Microbial production of recalcitrant dissolved organic matter: long-term carbon storage in the global ocean. Nat. Rev. Microbiol. 8, 593-599. doi: $10.1038 /$ nrmicro2386

Jiao, N., Robinson, C., Azam, F., Thomas, H., Baltar, F., Dang, H., et al. (2014). Mechanisms of microbial carbon sequestration in the ocean - future research directions. Biogeosciences 11, 5285-5306. doi: 10.5194/bg-11-5285-2014

Jiao, N., Tang, K., Cai, H., and Mao, Y. (2011). Increasing the microbial carbon sink in the sea by reducing chemical fertilization on the land. Nat. Rev. Microbiol. 9, 75-75. doi: 10.1038/nrmicro2386-c2

Jørgensen, N. O. G., Kroer, N., Coffin, R. B., and Hoch, M. P. (1999). Relations between bacterial nitrogen metabolism and growth efficiency in an estuarine and an open-water ecosystem. Aquat. Microb. Ecol. 18, 247-261. doi: 10.3354/ ame 018247

Kalvelage, T., Lavik, G., Jensen, M. M., Revsbech, N. P., Löscher, C., Schunck, H., et al. (2015). Aerobic microbial respiration in oceanic oxygen minimum zones. PLoS One 10:e0133526. doi: 10.1371/journal.pone. 0133526

Keeling, R. F., and Garcia, H. (2002). The change in oceanic $\mathrm{O}_{2}$ inventory associated with recent global warming. Proc. Natl. Acad. Sci. U.S.A. 99, 78487853. doi: 10.1073/pnas.122154899

Keeling, R. F., Körtzinger, A., and Gruber, N. (2010). Ocean deoxygenation in a warming world. Annu. Rev. Mar. Sci. 2, 199-299. doi: 10.1146/annurev.marine. 010908.163855

Laufkötter, C., John, J. G., Stock, C. A., and Dunne, J. P. (2017). Temperature and oxygen dependence of the remineralization of organic matter. Glob. Biogeochem. Cycles 31, 1038-1050. doi: 10.1002/2017GB005643

Lefèvre, D., Guigue, C., and Obernosterer, I. (2008). The metabolic balance at two contrasting sites in the Southern ocean: the iron-fertilised Kerguelen area and HNLC waters. Deep Sea Res. II Top. Stud. Oceanogr. 55, 766-776. doi: 10.1016/j.dsr2.2007.12.006

Lehner, P., Larndorfer, C., Garcia-Robledo, E., Larsen, M., Borisov, S. M., Revsbech, N.-P., et al. (2015). LUMOS - A sensitive and reliable optode system for measuring dissolved oxygen in the nanomolar range. PLoS One 10:e128125. doi: 10.1371/journal.pone.0128125

Lehner, P., Staudinger, C., Borisov, S. M., and Klimant, I. (2014). Ultra-sensitive optical oxygen sensors for characterization of nearly anoxic systems. Nat. Commun. 5:4460. doi: 10.1038/ncomms5460

Letscher, R. T., Knapp, A. N., James, A. K., Carlson, C. A., Santoro, A. E., and Hansell, D. A. (2015). Microbial community composition and nitrogen availability influence DOC remineralization in the South Pacific Gyre. Mar. Chem. 177, 325-334. doi: 10.1016/j.marchem.2015.06.024

Levin, K., Cashore, B., Bernstein, S., and Auld, G. (2012). Overcoming the tragedy of super wicked problems: constraining our future selves to ameliorate global climate change. Policy Sci. 45, 123-152. doi: 10.1007/s11077-012-9151-0

Li, W., and Gao, K. (2012). A marine secondary producer respires and feeds more in a high $\mathrm{CO}_{2}$ ocean. Mar. Pollut. Bull. 64, 699-703. doi: 10.1016/j.marpolbul. 2012.01.033

López-Urrutia, A., and Móran, X. A. G. (2007). Resource limitation of bacterial production distorts the temperature dependence of oceanic carbon cycling. Ecology 88, 817-822. doi: 10.1890/06-1641

López-Urrutia, A., San Martin, E., Harris, R. P., and Irigoien, X. (2006). Scaling the metabolic balance of the ocean. Proc. Natl. Acad. U.S.A. 103, 8739-8744. doi: 10.1073/pnas.0601137103

Loucaides, S., Tyrrell, T., Achterberg, E. P., Torres, R., Nightingale, P. D., Kitidis, V., et al. (2012). Biological and physical forcing of carbonate chemistry in an upwelling filament off northwest Africa: results from a Lagrangian study. Glob. Biogeochem. Cycles 26:GB3008. doi: 10.1029/2011GB004216

Martínez-García, S. (2017). Microbial respiration in the mesopelagic zone at Station ALOHA. Limnol. Oceanogr. 62, 320-333. doi: 10.1002/lno.10397

Martínez-García, S., Fernández, E., Aranguren-Gassis, M., and Teira, E. (2009). In vivo electron transport system activity: a method to estimate respiration in natural marine microbial planktonic communities. Limnol. Oceanogr. Methods 7, 459-469. doi: 10.4319/lom.2009.7.459

Martínez-García, S., Fernández, E., Calvo-Díaz, A., Cermeño, P., Marañón, E., Morán, X. A. G., et al. (2013). Differential response of microbial plankton to nutrient inputs in oligotrophic versus mesotrophic waters of the North Atlantic. Mar. Biol. Res. 9, 358-370. doi: 10.1080/17451000.2012.74 5002

Maske, H., Cajal-Medrano, R., and Villegas-Mendoza, J. (2017). Substrate-limited and -unlimited coastal microbial communities show different metabolic responses with regard to temperature. Front. Microbiol. 8:2270. doi: 10.3389/ fmicb.2017.02270

Mass, E. W., Law, C. S., Hall, J. A., Pickmere, S., Currie, K. I., Chang, F. H., et al. (2013). Effect of ocean acidification on bacterial abundance, activity and diversity in the Ross Sea, Antarctica. Aquat. Microb. Ecol. 70, 1-15. doi: 10.3354/ ame01633

Maugendre, L., Gattuso, J.-P., Poulton, A. J., Dellisanti, W., Gaubert, M., Guieu, C., et al. (2017). No detectable effect of ocean acidification on plankton metabolism in the NW oligotrophic Mediterranean Sea: results from two 
mesocosm studies. Estuar. Coast. Shelf Sci. 186, 89-99. doi: 10.1016/j.ecss.2015. 03.009

Mazuecos, I. P., Arístegui, J., Vázquez-Dominguez, E., Ortega-Retuerta, E., Gasol, J. M., and Reche, I. (2015). Temperature control of microbial respiration and growth efficiency in the mesopelagic zone of the South Atlantic and Indian Oceans. Deep Sea Res. I Oceanogr. Res. Pap. 95, 131-138. doi: 10.1016/j.dsr.2014. 10.014

McDonnell, A. M. P., Boyd, P. W., and Buesseler, K. O. (2015). Effects of sinking velocities and microbial respiration rates on the attenuation of particulate carbon fluxes through the mesopelagic zone. Glob. Biogeochem. Cycles 29, 175-193. doi: 10.1002/2014GB004935

Mercado, J. M., Sobrino, C., Neale, P. J., Segovia, M., Reul, A., Amorim, A. L., et al. (2014). Effect of $\mathrm{CO}_{2}$, nutrients and light on coastal plankton. II. Metabolic rates. Aquat. Biol. 22, 43-57. doi: 10.3354/ab00606

Moore, J. K., Fu, W. W., Primeau, F., Britten, G. L., Lindsay, K., and Long, M. (2018). Sustained climate warming drives declining marine biological productivity. Science 359, 1139-1142. doi: 10.1126/science.aao6379

Motegi, C., Tanaka, T., Piontek, J., Brussard, C. P. D., Gattuso, J.-P., and Weinbauer, M. G. (2013). Effect of $\mathrm{CO}_{2}$ enrichment on bacterial metabolism in an Arctic fjord. Biogeosciences 10, 8285-3296. doi: 10.5194/bg-10-3285-2013

Mukhanov, V., Rylkova, O., Lopukhina, O., and Kemp, R. B. (2003). Productivity and thermodynamics of marine bacterioplankton: an interecosystem comparison. Thermochim. Acta 397, 31-35. doi: 10.1016/S00406031(02)00313-1

Nelson, C. E., and Carlson, C. A. (2012). Tracking differential incorporation of dissolved organic carbon types among diverse lineages of Sargasso Sea bacterioplankton. Environ. Microbiol. 14, 1500-1516. doi: 10.1111/j.1462-2920. 2012.02738.x

Nguyen, D., Tremblay, J.-E., and Gosselin, M. (2012). Respiration and bacterial carbon dynamics in the Amundsen Gulf, western Canadian Arctic. J. Geophys. Res. 117:C00G16. doi: 10.1029/2011JC007343

Obernoster, I., Christaki, U., Lefèvre, D., Catala, P., van Wambeke, F., and Lebaron, P. (2008). Rapid bacterial mineralization of organic carbon produced during a phytoplankton bloom induced by natural iron fertilization in the Southern Ocean. Deep Sea Res. II Top. Stud. Oceanogr. 55, 777-789. doi: 10. 1016/j.dsr2.2007.12.005

Oschlies, A., Brandt, P., Stramma, L., and Schmidtko, S. (2018). Drivers and mechanisms of ocean deoxygenation. Nat. Geosci. 11, 467-473. doi: 10.1038/ s41561-018-0152-2

Osma, N., Fernández-Urruzola, I., Gómez, M., Montesdeoca-Esponda, S., and Packard, T. T. (2016). Predicting in vivo oxygen consumption rate from ETS activity and bisubstrate enzyme kinetics in cultured marine zooplankton. Mar. Biol. 163:146. doi: 10.1007/s00227-016-2923-x

Packard, T. T., Denis, M., Rodie, M., and Garfield, P. (1988). Deep-ocean metabolic $\mathrm{CO}_{2}$ production: calculations from ETS activity. Deep Sea Res. A Oceanogr. Res. Pap. 35, 371-382. doi: 10.1016/0198-0149(88)90016-7

Packard, T. T., Osma, N., Fernández-Urruzola, I., Codispoti, L. A., Christensen, J. P., and Gómez, M. (2015). Peruvian upwelling plankton respiration: calculations of carbon flux, nutrient retention efficiency, and heterotrophic energy production. Biogeosciences 12, 2641-2654. doi: 10.5194/bg-12-26412015

Paulmier, A., Kriest, I., and Oschlies, A. (2009). Stoichiometries of remineralisation and denitrification in global biogeochemical ocean models. Biogeosciences 6 , 923-935. doi: 10.5194/bg-6-923-2009

Paulmier, A., and Ruiz-Pino, D. (2009). Oxygen minimum zones (OMZs) in the modern ocean. Prog. Oceanogr. 80, 113-128. doi: 10.1016/j.pocean.2008.08.001

Paulmier, A., Ruiz-Pino, D., and Garcon, V. (2011). $\mathrm{CO}_{2}$ maximum in the oxygen minimum zone (OMZ). Biogeosciences 8, 239-252. doi: 10.5194/bg-8-239-2011

Piontek, J., Borchard, C., Sperling, M., Schulz, K. G., Riebesell, U., and Engel, A. (2013). Response of bacterioplankton activity in an Arctic fjord system to elevated pCO2; results from a mesocosm perturbation study. Biogeosciences 10, 297-314. doi: 10.5194/bg-10-297-2013

Piontek, J., Lunau, M., Handel, N., Borchard, C., Wurst, M., and Engel, A. (2010). Acidification increases microbial polysaccharide degradation in the ocean. Biogeosciences 7, 1615-1624. doi: 10.5194/bg-7-1615-2010

Regaudie-de-Gioux, A., and Duarte, C. M. (2012). Temperature dependence of planktonic metabolism in the ocean. Glob. Biogeochem. Cycles 26:GB1015. doi: 10.1029/2010GB003907
Regaudie-de-Gioux, A., and Duarte, C. M. (2013). Global patterns in oceanic planktonic metabolism. Limnol. Oceanogr. 58, 977-986. doi: 10.4319/lo.2013. 58.3.0977

Reinthaler, T., van Aken, H., Veth, C., Arístegui, J., Robinson, C., Williams, P. J., et al. (2006). Prokaryotic respiration and production in the meso- and bathypelagic realm of the eastern and western North Atlantic basin. Limnol. Oceanogr. 51, 1262-1273. doi: 10.4319/lo.2006.51.3.1262

Reinthaler, T., Winter, C., and Herndl, G. J. (2005). Relationship between bacterioplankton richness, respiration, and production in the southern North Sea. Appl. Environ. Microbiol. 71, 2260-2266. doi: 10.1128/AEM.71.5.22602266.2005

Revsbech, N. P., Larsen, L. H., Gundersen, J., Dalsgaard, T., Ulloa, O., and Thamdrup, B. (2009). Determination of ultra-low oxygen concentrations in oxygen minimum zones by the STOX sensor. Limnol. Oceanogr. Methods 7, 371-381. doi: 10.4319/lom.2009.7.371

Revsbech, N. P., Thamdrup, B., Dalsgaard, T., and Canfield, D. E. (2011). Construction of STOX oxygen sensors and their application for determination of $\mathrm{O}_{2}$ concentrations in oxygen minimum zones. Methods Enzymol. 486, 325-341. doi: 10.1016/S0076-6879(11)86014-3

Riebesell, U., and Gattuso, J.-P. (2014). Lessons learned from ocean acidification research. Nat. Clim. Chang. 5, 12-14. doi: 10.1038/nclimate2456

Riebesell, U., Schulz, K. G., Bellerby, R. G. J., Botros, M., Fritsche, P., and Meyerhöfer, M. (2007). Enhanced biological carbon consumption in a high $\mathrm{CO}_{2}$ ocean. Nature 450, 545-548. doi: 10.1038/nature06267

Riebesell, U., and Tortell, P. D. (2011). "Effects of ocean acidification on pelagic organisms and ecosystems," in Ocean Acidification, eds J.-P. Gattuso and L. Hansson (Oxford: Oxford University Press), 99-121.

Rivkin, R. B., and Legendre, L. (2001). Biogenic carbon cycling in the upper ocean: effects of microbial respiration. Science 291, 2398-2400. doi: 10.1126/science. 291.5512.2398

Robertson, J. E., Robinson, C., Turner, D. R., Holligan, P., Watson, A. J., Boyd, P., et al. (1994). The impact of a coccolithophore bloom on oceanic carbon uptake in the northeast Atlantic during summer 1991. Deep Sea Res. I Oceanogr. Res. Pap. 41, 297-314. doi: 10.1016/0967-0637(94)90005-1

Robertson, J. I. (1989). The Coulometric Determination of Total Inorganic Carbon in Seawater and the Study of the Inter-Relationship Between the Planktonic Metabolism of Carbon Dioxide and Oxygen. Ph.D. Thesis, University College of North Wales, Bangor.

Robinson, C. (2008). "Heterotrophic bacterial respiration," in Microbial Ecology of the Oceans, 2nd Edn, ed. D. L. Kirchman (Hoboken, NJ: John Wiley \& Sons, Inc).

Robinson, C., Archer, S. D., and Williams, P. J. (1999). Microbial dynamics in coastal waters of East Antarctica: plankton production and respiration. Microb. Ecol. Prog. Ser. 180, 23-36. doi: 10.3354/meps180023

Robinson, C., Serret, P., Tilstone, G., Teira, E., Zubkov, M. V., Rees, A. P., et al. (2002a). Plankton respiration in the Eastern Atlantic Ocean. Deep Sea Res. I Oceanogr. Res. Pap. 49, 787-813.

Robinson, C., Widdicombe, C. E., Zubkov, M. V., Tarran, G. A., Miller, A. E. J., and Rees, A. P. (2002b). Plankton community respiration during a coccolithophore bloom. Deep Sea Res. II Top. Stud. Oceanogr. 49, 2929-2950. doi: 10.1016/ S0967-0645(02)00064-4

Robinson, C., Wallace, D., Hyun, J.-H., Polimene, L., Benner, R., Zhang, Y., et al. (2018). An implementation strategy to quantify the marine microbial carbon pump and its sensitivity to global change. NatL. Sci. Rev. 5, 474-480. doi: 10.1093/nsr/nwy070

Robinson, C., and Williams, P. J. (2005). "Respiration and its measurement in surface marine waters," in Respiration in Aquatic Ecosystems, eds P. A. del Giorgio and P. J. Williams (Oxford: Oxford University Press).

Robinson, C., and Williams, P. J. L. (1999). Plankton net community production and dark respiration in the Arabian Sea during September 1994. Deep Sea Res. II Top. Stud. Oceanogr. 46, 745-765. doi: 10.1016/S0967-0645(98)00126-X

Rodrigues, R. M. N. V., and Williams, P. J. (2001). Heterotrophic bacterial utilisation of nitrogenous and non-nitrogenous substrates determined from ammonia and oxygen fluxes. Limnol. Oceanogr. 46, 1675-1683. doi: 10.4319/ lo.2001.46.7.1675

Romero-Kutzner, V., Packard, T. T., Berdalet, E., Roy, S. O., Gagné, J.-P., and Gómez, M. (2015). Respiration quotient variability: bacterial evidence. Mar. Ecol. Prog. Ser. 519, 47-59. doi: 10.3354/meps11062 
Roy, S. O., Packard, T. T., Berdalet, E., and St-Amand, L. (1999). Impact of acetate, pyruvate, and physiological state on respiration and respiratory quotients in Pseudomonas nautica. Aquat. Microb. Ecol. 17, 105-110. doi: 10.3354/ ame 017105

Sanders, R., Henson, S. A., Martin, A. P., Anderson, T. R., Bernardello, R., and Enderlein, P. (2016). Controls over ocean mesopelagic interior carbon storage (COMICS): fieldwork, synthesis and modelling efforts. Front. Mar. Sci. 3:136. doi: 10.3389/fmars.2016.00136

Sarmiento, J. L., and Gruber, N. (2006). Ocean Biogeochemical Dynamics. Princeton, NJ: Princeton University Press.

Schmidtko, S., Strammar, L., and Visbeck, M. (2017). Decline in global oceanic oxygen content during the past five decades. Nature 542, 335-341. doi: 10.1038/ nature 21399

Sondergaard, M., Williams, P. J., Cauwet, G., Riemann, B., Robinson, C., Terzic, S., et al. (2000). Net accumulation and flux of dissolved organic carbon and dissolved organic nitrogen in marine plankton communities. Limnol. Oceanogr. 45, 1097-1111. doi: 10.4319/lo.2000.45.5.1097

Sonnerup, R. E., Mecking, S., and Bullister, J. L. (2013). Transit time distributions and oxygen utilization rates in the Northeast Pacific Ocean from chlorofluorocarbons and sulfur hexafluoride. Deep Sea Res. I Oceanogr. Res. Pap. 72, 61-71. doi: 10.1016/j.dsr.2012.10.013

Sonnerup, R. E., Mecking, S., Bullister, J. L., and Warner, M. J. (2015). Transit time distributions and oxygen utilization rates from chlorofluorocarbons and sulfur hexafluoride in the Southeast Pacific Ocean. J. Geophys. Res. Oceans 120, 3761-3776. doi: 10.1002/2015JC010781

Spilling, K., Paul, A. J., Virkkala, N., Hastings, T., Lischka, S., Stuhr, A., et al. (2016). Ocean acidification decreases plankton respiration: evidence from a mesocosm experiment. Biogeosciences 13, 4707-4719. doi: 10.5194/bg-13-47072016

Stanley, R. H. R., Doney, S. C., Jenkins, W. J., and Lott, D. E. III (2012). Apparent oxygen utilization rates calculated from tritium and helium-3 profiles at the Bermuda Atlantic Time-series Study site. Biogeosciences 9, 1969-1983. doi: 10.5194/bg-9-1969-2012

Steinberg, D. K., Van Mooy, B. A. S., Buesseler, K. O., Boyd, P. W., Kobari, T., and Karl, D. M. (2008). Bacterial vs. zooplankton control of sinking particle flux in the ocean's twilight zone. Limnol. Oceanogr. 53, 1327-1338. doi: 10.4319/lo. 2008.53.4.1327

Stramma, L., Johnson, G. C., Sprintall, J., and Mohrholz, V. (2008). Expanding oxygen-minimum zones in the tropical oceans. Science 320, 655-658. doi: 10 . 1126/science. 1153847

Tamburini, C., Boutrif, M., Garel, M., Colwell, R. R., and Deming, J. W. (2013). Prokaryotic responses to hydrostatic pressure in the ocean - a review. Environ. Microbiol. 15, 1262-1274. doi: 10.1111/1462-2920.12084

Tanaka, T., Alliouane, S., Bellerby, R. G. B., Czerny, J., de Kluijver, A., Riebesell, U., et al. (2013). Effect of increased $\mathrm{pCO}_{2}$ on the planktonic metabolic balance during a mesocosm experiment in an Arctic fjord. Biogeosciences 10, 315-325. doi: 10.5194/bg-10-315-2013

Teira, E., Hernando-Morales, V., Martínez-García, S., Figueiras, F. G., Arbones, B., and Álvarez-Salgado, X. A. (2013). Response of bacterial community structure and function to experimental rainwater additions in a coastal eutrophic embayment. Estuar. Coast. Shelf Sci. 119, 44-53. doi: 10.1016/j.ecss.2012. 12.018
Thomas, H. (2002). Remineralization ratios of carbon, nutrients, and oxygen in the North Atlantic Ocean: a field databased assessment. Glob. Biogeochem. Cycles 16:1051. doi: 10.1029/2001GB001452

Tiano, L., Garcia-Robledo, E., Dalsgaard, T., Devol, A. H., Ward, B. B., Ulloa, O., et al. (2014). Oxygen distribution and aerobic respiration in the north and south eastern tropical Pacific oxygen minimum zones. Deep Sea Res. I Oceanogr. Res. Pap. 94, 173-183. doi: 10.1016/j.dsr.2014.10.001

Van Mooy, B., Keil, R., and Devol, A. (2002). Impact of suboxia on sinking particulate organic carbon: enhanced carbon flux and preferential degradation of amino acids via denitrification. Geochem. Cosmochim. Acta 66, 457-465. doi: 10.1016/S0016-7037(01)00787-6

Wear, E. K., Carlson, C. A., Windecker, L. A., and Brzezinski, M. A. (2015). Roles of diatom nutrient stress and species identity in determining the short- and longterm bioavailability of diatom exudates to bacterioplankton. Mar. Chem. 177, 335-348. doi: 10.1016/j.marchem.2015.09.001

Weber, T., Cram, J. A., Leung, S. W., DeVries, T., and Deutsch, C. (2016). Deep ocean nutrients imply large latitudinal variation in particle transfer efficiency. Proc. Natl. Acad. Sci. U.S.A. 113, 8606-8611. doi: 10.1073/pnas.1604414113

Weinbauer, M. G., Liu, J., Motegi, C., Maier, C., Pedroti, M. L., Dai, M., et al. (2013). Seasonal variability of microbial respiration and bacterial and archaeal community composition in the upper twilight zone. Aquat. Microb. Ecol. 71, 99-115. doi: 10.3354/ame01666

Williams, P. J. B., and del Giorgio, P. A. (2005). "Respiration in aquatic ecosystems: history and background," in Respiration in Aquatic Ecosystems, eds P. A. del Giorgio and P. J. Williams (Oxford: Oxford University Press), 315.

Wohlers, J., Engel, A., Zöllner, E., Breithaupt, P., Jürgens, K., Hoppe, H.-G., et al. (2009). Changes in biogenic carbon flow in response to sea surface warming. Proc. Natl. Acad. Sci. U.S.A. 106, 7067-7072. doi: 10.1073/pnas.0812743106

Wood, E. S. (1992). The Community Photosynthetic Quotient and the Assimilation of Nitrogen by Oceanic Plankton. Ph.D. Thesis, University College of North Wales, Bangor.

Wright, J. J., Konwar, K. M., and Hallam, S. J. (2012). Microbial ecology of expanding oxygen minimum zones. Nat. Rev. Microbiol. 10, 381-394. doi: 10. 1038/nrmicro2778

Yvon-Durocher, G., Caffrey, J. M., Cescatti, A., Dossena, M., del Giorgio, P., and Gasol, J. M. (2012). Reconciling the temperature dependence of respiration across timescales and ecosystem types. Nature 487, 472-476. doi: 10.1038/ nature11205

Zhang, C., Dang, H., Azam, F., Benner, R., Legendre, L., Passow, U., et al. (2018). Evolving paradigms in biological carbon cycling in the ocean. Natl. Sci. Rev. 5, 481-499. doi: 10.1093/nsr/nwy074

Conflict of Interest Statement: The author declares that the research was conducted in the absence of any commercial or financial relationships that could be construed as a potential conflict of interest.

Copyright (c) 2019 Robinson. This is an open-access article distributed under the terms of the Creative Commons Attribution License (CC BY). The use, distribution or reproduction in other forums is permitted, provided the original author(s) and the copyright owner(s) are credited and that the original publication in this journal is cited, in accordance with accepted academic practice. No use, distribution or reproduction is permitted which does not comply with these terms. 